\title{
The hormonal response to exercise
}

\section{By Henrik Galbo, Department of Medical Physiology B, The Panum Institute, University of Copenhagen, 2200 Copenhagen $N$, Denmark}

In the present paper, the hormonal (or rather the autonomic neuroendocrine) changes elicited during exercise are outlined. The author's working hypothesis concerning the control of the hormonal response to exercise is mentioned, and the influence of the autonomic neuroendocrine system on exercise metabolism is discussed. The exposition is mainly based on the documentation given in Galbo (1983). However, studies quoted in that book will not be explicitly referred to here. Instead references will be given to recent work not included in Galbo ( 1983 ).

Most information on exercise endocrinology is derived from experiments in man. However, recent animal studies will be emphasized and species differences of which the author is aware will be mentioned.

\section{Hormonal changes during exercise}

During exercise, the activity in the sympathoadrenal neuroendocrine system, and accordingly the concentrations in plasma of the catecholamines, noradrenaline, adrenaline and dopamine, increase in higher vertebrates. In man, it has been shown that essentially the increase in catecholamines is directly related to oxygen uptake $\left(\dot{V}_{\mathrm{O}_{2}}\right)$, but that at a certain $\dot{V}_{\mathrm{O}_{2}}$, catecholamine levels are higher during work with small muscle groups with a low muscle group specific $\dot{V}_{\mathrm{O}_{2}} \max$ than during work with large muscle groups with a high $\dot{V}_{\mathrm{O}_{2}} \max$ (Lewis et al. 1983). Also in the primitive vertebrate, the dogfish shark, which lacks a functioning sympathetic nervous system, an exercise-induced increase in plasma catecholamine concentrations has been found (Opdyke et al. 1982).

The increase in sympathoadrenal activity is of major importance for the cardiovascular adaptation (Christensen \& Galbo, 1983) and thermoregulation in exercise, but not for the changes in ventilation and airway resistance (Folgering et al. 1982; Tesch \& Kaiser, 1983). The cardiac frequency and force of contraction are enhanced, the tone of arterioles in the splanchnic area, kidneys and non-contracting muscles and of veins is increased, and the spleen, at least in dogs, brought to contract. In this way, cardiac output is enhanced and blood volume and flow redistributed in favour of skin and working muscle. Stimulation of sweat glands increases evaporative heat loss. If adrenergic activity is impeded, exercise capacity is reduced (Folgering et al. 1982 ; Tesch \& Kaiser, I983).

Sweating implies loss of water and electrolytes from the body. However, sympathoadrenal activity also has effects on water and electrolyte balances, reducing such losses in exercise. By decreasing renal blood flow and changing its distribution, and by direct tubular effects, sympathoadrenal activity diminishes renal sodium and water losses. Furthermore, during exercise sympathoadrenal 
activity mainly via $\beta$-adrenergic mechanisms releases renin from the kidneys (Joles et al. 1982; Zambraski et al. 1984). The resulting increase in plasma angiotensin concentration promotes the secretion of aldosterone and antidiuretic hormone $(\mathrm{ADH})$ and, accordingly, renal $\mathrm{Na}$ and water excretion is reduced (Milledge \& Catley, 1982; Convertino et al. 1983 ). Sympathoadrenal activity diminishes loss of potassium by facilitating muscular uptake of $\mathrm{K}$.

The most important effect of sympathoadrenal activity on hormone secretion in exercise is an $\alpha$-adrenergic inhibition of insulin release. In man, this inhibition is exerted by sympathetic nerves, while in the rat (Richter, 1984) and in sheep (Brockman, 1982; Brockman \& Halvorson, 1982) adrenaline is involved. In man and dog, an exercise-induced increase in plasma glucagon levels is only seen when exercise is prolonged. In man, decreasing glucose availability rather than adrenergic activity has been found to account for this increase. In the dog, however, pancreatic nervous activity is involved in the glucagon release. Furthermore, in rats and sheep, the glucagon concentration increases early in exercise, and the increase is at least partly due to adrenergic activity (Brockman, I982; Brockman \& Halvorson, I982; Richter, 1984). Adrenergic activity modulates the exercise-induced increase in pancreatic polypeptide (PP) levels in plasma. It may also account for the small increase in gastrin concentrations and, possibly, for the increase in parathyroid hormone levels, which has been found in steers exercising in a low-pressure chamber. Finally, adrenergic activity exerts an inotropic effect in skeletal muscle (Aubier et al. 1984), as it does in the heart.

The plasma concentrations of the anterior pituitary hormones, growth hormone (GH) (Bullen et al. 1984; Vanhelder et al. 1984), adrenocorticotrophic hormone (ACTH) (Tabata et al. 1984), prolactin (PRL) (Brisson et al. 1981 ; Shangold et al. I98I) and thyroid stimulating hormone (TSH) (Schmid et al. I982) may increase in exercise. The ACTH increase results in an increase in cortisol secretion in man (Brandenberger \& Follenius, 1975; Few \& Thompson, 1980; Brandenberger et al. 1982) and increased corticosterone levels in rats (Guezennec et al. 1982) and ducks (Harvey \& Phillips, 1982). An exercise-induced increase in thyroxine secretion has been found in horses, but could not be unambiguously demonstrated in man and rats. Furthermore, the plasma concentrations of thyroid hormones, the levels of mitochondrial enzymes dependent on these hormones, and basal metabolic rate are essentially not changed by exercise.

In man, the levels of follicle-stimulating hormone (FSH) and luteinizing hormone (LH) are unchanged during exercise. Nevertheless, increases in the concentrations of gonad hormones may be seen. These are probably due to haemoconcentration and decreases in clearance (Weiss et al. 1983). In men, an early exercise-induced increase in plasma testosterone concentration gradually wanes if exercise is continued, probably in consequence of reduced secretion rate. In male rats, a decrease in plasma LH levels is probably responsible for the decrease in plasma testosterone seen during prolonged running (Guezennec $e t$ al. 1982). The plasma concentration of ADH may, as mentioned, increase in exercise, but the evidence for an increase in the levels of the other posterior pituitary 
hormone, oxytocin, is weak (Landgraf et al. 1982). In women, the circulating levels of the pineal indoleamine melatonin have been shown to increase during heavy bicycle exercise (Bullen et al. 1984).

During prolonged exercise, the concentrations in plasma of the peptides vasoactive intestinal polypeptide (VIP), secretin, somatostatin (SRIF), met-enkephalin and $\beta$-endorphin may increase (Farrell et al. 1982; Bullen et al. 1984; Elliot et al. 1984; Howlett et al. 1984; Metzger \& Stein, 1984). These peptides are, as PP and gastrin, synthesized in endocrine cells in the gastroenteropancreatic area as well as in nerve cells within as well as outside the central nervous system (CNS). Neither do we know the origin of and stimulus for their release in exercise, nor their role in this condition.

\section{The post-exercise period}

At the beginning of the recovery period, the metabolic rate, although lower than in exercise, is still increased, glycogen stores in the exercised muscles are depleted, excess heat is stored and the fluid volume is diminished and redistributed. Accordingly, there is a need for fuel mobilization, fuel redistribution, cardiovascular adaptation, and conservation of water and electrolytes. However, the need is less than in exercise and decreasing towards basal needs. It should be remembered that the derangement in the body after exercise is determined by the preceding muscular activity (e.g. as regards intensity, duration and environment), and that complete return to the pre-exercise state requires rest as well as intake of food and fluid.

After short-term, heavy exercise, derangement of homeostasis is not profound and normalization of hormone levels is rather fast (Galbo \& Gollnick, 1984). Immediately after this type of exercise, there may even be a rebound increase in insulin concentrations reflecting a sudden diminution of adrenergic inhibition of the pancreatic $\beta$-cells.

After prolonged exhaustive exercise, the derangement of homeostasis is marked and plasma hormone concentrations only return slowly towards basal values (Galbo \& Gollnick, 1984; Tabata et al. 1984). The slow hormonal recovery reflects the rate with which the stimuli underlying the hormonal changes are normalized, but may also reflect that a change in sensitivity of hormonal secretion to stimulation has developed during exercise. Thus, after a single bout of prolonged exercise, the insulin concentration in plasma remains low for a long time, and this kind of exercise also results in a reduced insulin response to glucose (James et al. I983).

In studies of the effect of regularly repeated exercise (training), the effect of the last bout of exercise per se is not always sorted out. However, it has been shown that training causes a more prolonged suppression of glucose-stimulated insulin secretion than does acute exercise (James et al. 1983). Athletes have lower basal glucagon concentrations and higher responses of epinephrine and $\mathrm{GH}$ to hypoglycaemia than sedentary subjects (Kjar et al. 1984). In women, endurance training has been reported to influence the pituitary-thyroid axis (Boyden $e t$ al. 
$1982 a, b, 1984)$. However, the findings were not convincing, since the changes were small and not directly related to amount of training. At the end of training, a decreased TSH response to thyrotropic releasing hormone (TRH) was found (Boyden et al. 1984).

The same group has reported a small increase in the TRH stimulated PRL response after training and has proposed that exercise-induced increases in PRL are involved in the etiology of altered menstrual cycle function in women engaged in endurance training (Boyden et al. 1982a,b; Shangold \& Levine 1982). Menstrual irregularities correlate positively with amount of training (Russell et al. 1984) and are particularly seen in girls with late menarche and in girls who start training before menarche (Wakat et al. 1982). In men, androgen levels may decrease below levels at rest in the post-exercise period. However, daily exercise for $5 \mathrm{~d}$ did not decrease basal testosterone levels or sperm production rates (McConnell \& Sinning, 1984). A more prolonged period of training may decrease basal testosterone and increase total oestrogen levels in men (Basset Frey et al. 1983). Multifactorial stress which includes daily exercise has been shown to depress testicular function and to cause a number of other complex endocrine changes (Aakvaag et al. 1978; Oektedalen et al. 1982, 1983; Opstad \& Aakvaag, 1983; Opstad et al. 1984).

\section{Control of the hormonal response to exercise}

The time-course of hormonal changes during exercise and in the post-exercise period, at the start of which activity in motor centres within the CNS and the flow of impulses from mechanoreceptors suddenly cease, indicates that the regulation of the autonomic neuroendocrine response to exercise has a fast nervous component and a slow 'internal milieu' component. 'The response may be regulated as follows: at the onset of exercise, impulses from motor centres in the brain as well as from working muscles elicit a work-load dependent increase in sympathoadrenal activity and in release of some pituitary hormones (GH, ACTH, PRL, possibly TSH). These changes, then, control the changes in secretion of subordinate endocrine cells: sympathoadrenal activity depresses insulin secretion and stimulates the renin-angiotensin-ADH system and the secretion of PP (and of glucagon in some subhuman species), and possibly the secretion of PTH and gastrin as well. ACTH stimulates adrenal cortical secretion.

The state of the organism before exercise is important for the magnitude of the hormonal response. Thus, experiments with trained and untrained subjects (Harvey \& Phillips, 1982; Convertino et al. 1983; Lacour et al. 1983; Howlett et al. 1984), with inhalation of air rich or poor in $\mathrm{O}_{2}$ (Milledge \& Catley, 1982; Sutton, 1983), with small or large muscle groups (Lewis et al. 1983), with different exercise protocols (Vanhelder et al. 1984), and with patients with heart failure (Francis et al. 1982) or cardiac pacing (Galbo \& Gollnick, 1984) have shown that the hormonal response to exercise depends on the relative rather than on the absolute work intensity, i.e. the response at a given $\dot{V}_{\mathrm{O}_{2}}$ being lower if $\dot{V}_{\mathrm{O}_{2} \max }$ is high than if it is low. Furthermore, experiments with fasted (Galbo et al. $198 \mathrm{r}$ ) or 
fat-fed (Jansson et al. 1982) healthy subjects, diabetics (Viberti et al. 1984) and obese subjects (Jakober et al. 1983 ) have indicated that the concentrations of other hormones are higher during exercise when insulin availability is lower than normal in the time preceding exercise. Finally, the hormonal response to exercise may be influenced by disease (e.g. blunted sympathoadrenal response to exercise in asthmatic subjects (Barnes et al. 1981; Warren et al. 1982)).

If exercise is continued, the hormonal changes may be gradually intensified by impulses from receptors sensing changes in glucose concentrations (Felig et al. 1982; Winder et al. 1982; Kozlowski et al. 1983; Tabata et al. 1984), temperature (Powers et al. 1982), intravascular volume and $\mathrm{O}_{2}$ tension.

\section{Essential features of exercise metabolism (Fig. I)}

I. The hormonal response to exercise is essentially non-discriminating, promoting mobilization of both glycogen and triglyceride from extra- as well as intramuscular stores (Brockman, I982; Brockman \& Halvorson, 1982; Oscai et al. 1982; Chasiotis et al. 1983; McLeod et al. 1984; Richter, 1984; Simonson et al. 1984). Breakdown of the latter is also enhanced directly by contractions. The quantity of fuel mobilized from the different stores depends not only on the hormonal response and contractile activity, but also on the size of the fuel depots as well as on the state of hormone receptors and capacity of involved enzymes in these depots.

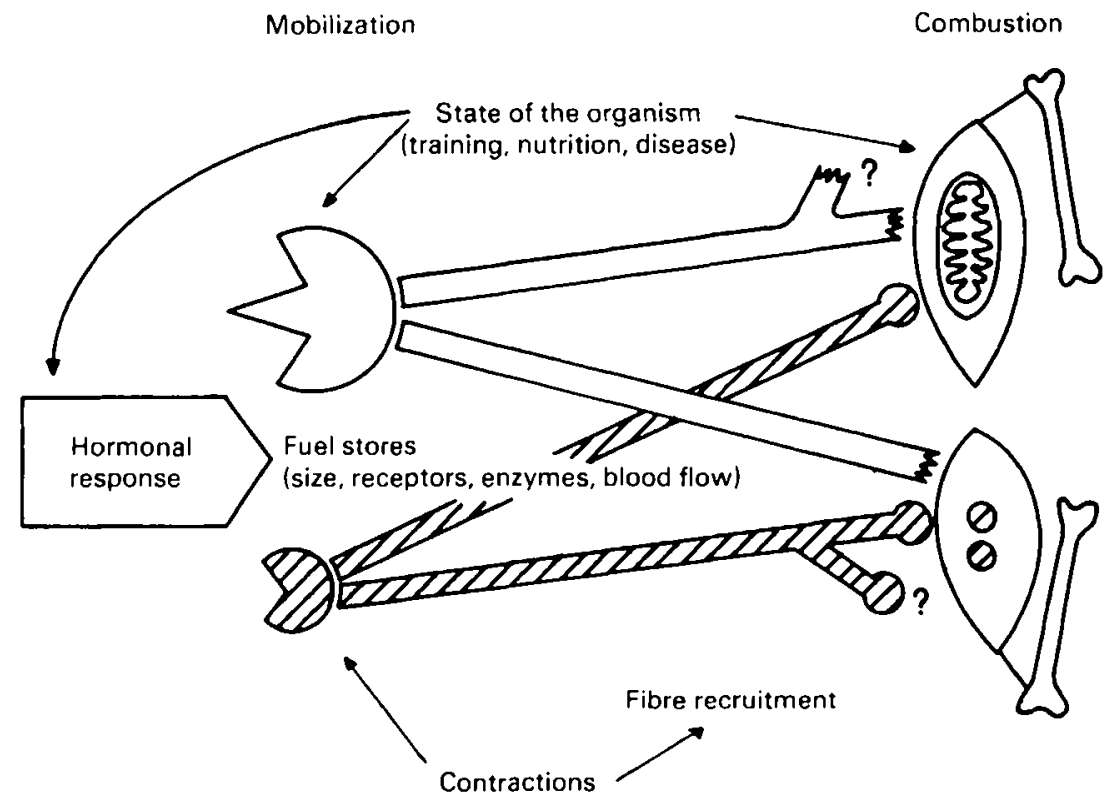

Fig. I. The factors regulating metabolism in exercise. Two kinds of fuel stores (carbohydrate and lipid, being extra- or intramuscular) and two types of muscle fibres (either rich or poor in mitochondria and, accordingly, with different substrate preference) are indicated. Question marks indicate excess mobilization of fuel and futile cycling. 
(a) ACUTE INHIBITION OF MOBIIIZATION OF A FUEL

Intramuscular glycogenolysis

Hepatic glucose production

lipolysis

(b) EXOGENOUS ADMINISTRATION OF A FUEL.
$\Leftrightarrow$ increased mobilization and COMBUSTION OF OTHER FUELS

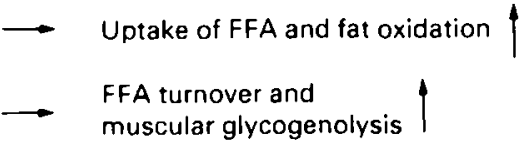

Hepatic and muscular glycogenolysis and carbohydrate oxidation

INCREASED COMBUSTION OF THAT FUEL: INHIBITED MOBILIZATION AND COMBUSTION OF OTHER FUELS

Glucose oxidation

Glucose

$\longrightarrow$ Mobilization and oxidation of endogenous carbohydrate and lipid

Fat oxidation

FFA
Breakdown of glycogen in liver and muscle. muscular glucose uptake and triglyceride breakdown

Fig. 2. Summary of evidence indicating that intra- and extramuscular energy stores can substitute for each other. (a) Acute inhibition of mobilization of a fuel, $(b)$ exogenous administration of a fuel. FFA, free fatty acid.

Quantitatively, protein is a relatively-unimportant fuel during exercise (CallesEscandon et al. 1984; Plante \& Houston, 1984). Exercise may cause a loss of liver protein (Kasperek et al. 1982). In isolated muscle, synthesis as well as degradation of protein are inhibited during contractions (Bylund-Fellenius et al. 1984). The hormonal influence on protein metabolism in exercise has not been studied very much. However, it has been found that in the working heart protein degradation is higher in the absence than in the presence of insulin (Smith \& Sugden, 1983). Furthermore, adrenomedullary hormones have been shown not to influence hepatic and muscular protein concentrations in exercising rats (Richter et al. 1984).

2. The different intra- and extramuscular energy stores can substitute for each other. This has appeared from studies in which the mobilization of fuel was acutely inhibited by drugs (Fig. 2(a)) or supplemented by exogenous administration (Fig. 2(b)) (Kozlowski et al. 1983; Levine et al. 1983; Werner et al. 1983; Hargreaves et al. 1984). Uptake of blood-borne substrates depends in part on mass effects, and extra- and intramuscular fuels are burned in competition with each other (Walker et al. 1984). Mobilization of intramuscular fuel is not mainly called on when 
delivery of exogenous fuel is insufficient. In favour of this view, it has been shown in a well-oxygenated hind-limb preparation that at intense muscle contraction, increased combustion of endogenous glycogen and triglyceride was accompanied by a decrease in uptake of glucose and free fatty acids, in spite of increased delivery of these blood-borne fuels (Walker et al. 1984). The final choice of fuel depends on availability of substrates and on the capacity of the metabolizing, energy-yielding enzymic pathways (Bünger et al. 1982).

3. During exercise of a fixed intensity, the state of the organism before the studied moment of exercise (e.g. as regards nutrition (Minuk et al. 1980; Phinney et al. 1980; Horton, 1982; Jansson \& Kaijser, 1982), degree of training (Williams \& Bishop, 1982; Després et al. 1984; Martin et al. 1984; Williams et al. 1984), hormone levels in plasma (Ianuzzo et al. 1982), and level of physical activity (McLeod et al. 1984; Michel et al. 1984)) influences the induced hormonal changes, the sensitivity of fuel depots to stimulation, as well as the capacity of the recruited muscle fibres for metabolism of the different substrates.

4. Mobilization of extramuscular fuel is regulated in a 'feed-forward' fashion rather than by 'feed-back' mechanisms coupled to the minimal needs of the exercising muscles. In accordance with this view, it has been shown in running rats that hepatic glycogen is mobilized and glucose forced on the muscles at a time at which they are rich in endogenous fuel (Sonne \& Galbo, 1983, 1984). Furthermore, studied at the same exercise intensity, $\mathrm{O}_{2}$ uptake, and muscular glycogen concentration, hepatic glucose production was higher in experiments in which hepatic glycogen stores had been increased by fructose than in experiments in which hepatic glycogen had been depleted before exercise (Sonne \& Galbo, 1984).

5. Mobilization of extra- and intramuscular fuel is probably neither accurately nor optimally matching the energy demands of the contractile machinery. Exact regulation would hardly be compatible with the previously-mentioned characteristics $(\mathrm{I}-4)$. Nor would it be compatible with the fact that during exercise changes in the plasma levels of hormones influencing metabolism are not geared exclusively to metabolic needs, but are also adjusted to serve control of circulation, volume and osmolality of body fluids, and temperature. Rather, one would expect that, to some extent, mobilized energy sources after a shorter or longer travel would be 'buffered' by re-storage ('futile cycling', Brooks et al. 1982).

In fact, there is evidence that mobilization of energy sources in response to exercise may exceed energy expenditure, some of the mobilized fuel being accumulated extracellularly or stored in intra- or extramuscular depots. Nevertheless, fuel mobilization may be suboptimal, limiting performance at a time at which triglyceride stores are plentiful.

The author received support from the Danish Medical Research Council (J. nr. 3817). 


\section{REFERENCES}

Aakvaag, A., Bentdal, Ø., Quigstad, K., Walstad, P., Rønningsen, H. \& Fonnum, F. (1978). International Fournal of Andrology 1, 22-31.

Aubier, M., Viires, N., Murciano, D., Medrano, G., Lecocgiuc, Y. \& Pariente, R. (1984). Fournal of Applied Physiology 56, 922-929.

Barnes, P. J., Brown, M. J., Silverman, M. \& Dollery, C. T. (1981). Thorax 36, 435-440.

Basset Frey, M. A., Doerr, B. M., Srivastava, L. S. \& Glueck, C. J. (1983). Fournal of Applied Physiology 54, 757-762.

Boyden, T. W., Pamenter, R. W., Grosso, D., Stanforth, P., Rotkis, T. \& Wilmore, J. H. (1982b). fournal of Clinical Endocrinology and Metabolism 54, $71 \mathrm{I}-7 \mathrm{I} 4$.

Boyden, T. W., Pamenter, R. W., Rotkis, T. C., Stanforth, P. \& Wilmore, J. H. (1984). Medicine and Science in Sports and Exercise 16, 243-246.

Boyden, T. W., Pamenter, R. W., Stanforth, P., Rotkis, T. \& Wilmore, J. H. (1982a). fournal of Clinical Endocrinology and Metabolism 53, 53-56.

Brandenberger, G. \& Follenius, M. (1975). Journal of Clinical Endocrinology and Metabolism 40, $845^{-8}-89$.

Brandenberger, G., Follenius, M., Hietter, B., Reinhardt, B. \& Siméoni, M. (1982). Fournal of Clinical Endocrinology and Metabolism 54, 592-596.

Brisson, G. R., Ledoux, M., Péronnet, F., Dulac, S., DeCarufel, D., Volle, M. A., Rainville, J. \& Audet, A. (1981). Hormone Research $15,218-223$.

Brockman, R. P. (1982). Canadian fournal of Physiology and Pharmacology 60, 1459-1463.

Brockman, R. P. \& Halvorson, R. (1982). Fournal of Applied Physiology 52, 31 5-319.

Brooks, B., Arch, J. R. S. \& Newsholme, E. A. (I982). FEBS Letters 146, 327-330.

Bullen, B. A., Skrinar, G. S., Beitins, I. Z., Carr, D. B., Reppert, S. M., Dotson, C. O., de M. Fencl, M., Gervino, E. V. \& McArthur, J. W. (1984). Gournal of Applied Physiology 56, 1453-1463.

Bünger, R., Permanetter, B., Sommer, O. \& Yaffe, S. (1982). American fournal of Physiology 242, $\mathrm{H}_{3} \circ-\mathrm{H}_{3} 6$.

Bylund-Fellenius, A-C., Ojamaa, K. M., Flaim, K. E., Li, J. B., Wassner, S. J. \& Jefferson, L. S. ( 1984 ). American Journal of Physiology 246, E297- $\mathrm{E}_{3} \mathrm{O}_{5}$.

Calles-Escandon, J., Cunningham, J. J., Snyder, P., Jacob, R., Huszar, G., Loke, J. \& Felig, P. (1984). American Journal of Physiology 246, E334-338.

Chasiotis, D., Brandt, R., Harris, R. C. \& Hultman, E. (1983). American fournal of Physiology 245, EI 66- E 170.

Christensen, N. J. \& Galbo, H. (1983). Annual Review of Physiology 45, 139-1 53 .

Convertino, V. A., Keil, L. C. \& Greenleaf, J. E. (1983). Fournal of Applied Physiology 54, 508-514.

Despres, J. P., Bouchard, C., Savard, R., Tremblay, A., Marcotte, M. \& Theriault, G. (1984). Metabolism 33, 235-239.

Elliot, D. L., Goldberg, L., Watts, W. J. \& Orwoll, E. (1984). Life Sciences 34, 515-518.

Farrell, P. A., Ward, K. G., Maksud, M. G. \& Morgan, W. P. (1982). Gournal of Applied Physiology 52, $1245^{-1249}$.

Felig, P., Cherif, A., Minagawa, A. \& Wahren, J. (1982). New England Yournal of Medicine 306, $895-900$.

Few, J. D. \& Thompson, M. W. (1980). Acta Endocrinologica 94, 204-21 2.

Folgering, H.Th. M., Borm, J. F. E. \& van Haaren, R. H. L. M. (1982). European fournal of Clinical Pharmacology 23, 283-288.

Francis, G. S., Goldsmith, S. R., Ziesche, S. M. \& Cohn, J. N. (1982). American Fournal of Cardiology 49, I I 52- 1156.

Galbo, H. (1983). Hormonal and Metabolic Adaptation to Exercise, pp. I-1 16, 1st edition. Stuttgart and New York: Thieme-Stratton Inc.

Galbo, H., Christensen, N. J., Mikines, K. J., Sonne, B., Hilsted, J., Hagen, C. \& Fahrenkrug, J. (1981). Fournal of Clinical Endocrinology and Metabolism 52, 1 106- 1112.

Galbo, H. \& Gollnick, P. D. (1984). Medicine and Sport Science 1 7, 97-1 10.

Guezennec, C. Y., Ferre, P., Serrurier, B., Merino, D. \& Pesquies, P. C. (1982). European fournal of Applied Physiology 49, 1 59-168.

Hargreaves, M., Costill, D. L., Coggan, A., Fink, W. J. \& Nishibata, I. (1984). Medicine and Science in Sports and Exercise 16, $219-222$. 
Harvey, S. \& Phillips, J. G. (1982). Fournal of Endocrinology 94, 141-146.

Horton, E. S. (1982). American fournal of Clinical Nutrition 35, 1 228-1233.

Howlett, T. A., Tomlin, S., Ngahfoong, L., Rees, L. H., Bullen, B. A., Skrinar, G. S. \& McArthur, J. W. (1984). British Medical Journal 288, 1950-1952.

Ianuzzo, C. D., Noble, E. G., Hamilton, N. \& Dabrowski, B. (1982). Journal of Applied Physiology 52, $1471-1475$.

Jakober, B., Schmülling, R. M., Müler, P. H. \& Eggstein, M. (1983). Yournal of Endocrinological Investigation 6, 445-453.

James, D. E., Burleigh, K. M., Kraegen, E. W. \& Chisholm, D. J. (1983). Fournal of Applied Physiology 55, I660- 1664 .

Jansson, E., Hjemdah, P. \& Kaijser, L. (1982). Acta Physiologica Scandinavica 114, 171-178.

Jansson, E. \& Kaijser, L. (I982). Acta Physiologica Scandinavica I 15, I9-30.

Joles, J. A., den Hertog, J. M., Huisman, G. H., Kraan, W. J., van Schaik, F. W. \& Schrikker, A. C. (1982). European fournal of Applied Physiology 49, I I I-I 19.

Kasperek, G. J., Dohm, G. L., Barakat, A., Strausbauch, P. H., Barnes, D. W. \& Snider, R. D. (1982). Biochemical fournal 202, $28 \mathrm{I}-\mathbf{2 8 8}$.

Kjær, M., Mikines, K. J., Christensen, N. J., Tronier, B., Vinten, J., Sonne, B., Richter, E. A. \& Galbo, H. (1 984). Fournal of Applied Physiology 57, $21-27$.

Kozlowski, S., Nazar, K., Brzezinska, Z., Kaciuba-Uscilko, H. \& Kobryn, A. (1983). Pflügers Archiv 399, 63-67.

Lacour, J.-R., Pequignot, J.-M., Geyssant, A., Coudert, J. \& Peyrin, L. (1983). Fournal of Physiology (Paris) 78, 838-842.

Landgraf, R., Häcker, R. \& Buhl, H. (1982). Endokrinologie 79, 281-291.

Levine, L., Evans, W. J., Cadarette, B. S., Fisher, E. C. \& Bullen, B. A. (1983). Fournal of Applied Physiology 55, 1 767-1771.

Lewis, S. F., Taylor, F. W., Graham, R. M., Pettinger, W. A., Schutte, J. E. \& Blomquist, C. G. (1983). Fournal of Applied Physiology 54, $1314-1323$.

McConnell, T. R. \& Sinning, W. E. (I984). Medicine and Science in Sports and Exercise 18, 5 I-55.

McLeod, A. A., Brown, J. E., Kitchell, B. B., Sedor, F. A., Kuhn, C., Shand, D. G. \& Williams, R. S. (1984). Fournal of Applied Physiology 56, 716-722.

Martin, W. H., Coyle, E. F., Joyner, M., Santeusanio, D., Ehsani, A. A. \& Holloszy, J. O. (1984). fournal of Applied Physiology 56, $845-848$.

Metzger, J. M. \& Stein, E. A. (1984). Life Sciences 34, 154 I-1547.

Michel, G., Vocke, T., Fiehn, W., Weicker, H., Schwarz, W. \& Bieger, W. P. (1984). American fournal of Physiology 246, Er 53 -Er 59.

Milledge, J. S. \& Catley, D. M. (1982). Fournal of Applied Physiology 52, 320-323.

Minuk, H. L., Hanna, A. K., Marliss, E. B., Vranic, M. \& Zinman, B. (1980). American Yournal of Physiology 238, $\mathrm{E}_{322}-\mathrm{E}_{329}$.

Oektedalen, O., Opstad, P. K. \& Schaffalitzky de Muckadell, O. B. (1982). Regulatory Peptides 4, $213-219$.

Oektedalen, O., Opstad, P. K., Schaffalitzky de Muckadell, O. B., Fausa, O. \& Flaten, O. (1983). Regulatory Peptides 5, 235-244.

Opdyke, D. F., Carroll, R. G. \& Keller, N. E. (1982). American Fournal of Physiology 242, $\mathrm{R}_{306}-\mathrm{R}_{3}$ I0.

Opstad, P. K. \& Aakvaag, A. (1983). European fournal of Applied Physiology 51, 97-107.

Opstad, P. K., Falch, D., Oektedalen, O., Fonnum, F. \& Wergeland, R. (1984). Clinical Endocrinology 20, 657-669.

Oscai, L. B., Caruso, R. A. \& Wergeles, A. C. (1982). Fournal of Applied Physiology 52, $1059-1063$.

Phinney, S. D., Horton, E. S., Sims, E. A. H., Hanson, J. S., Danforth, E. Jr. \& LaGrange, B. M. (1980). Fournal of Clinical Investigation 66, $1152-1161$.

Plante, R. I. \& Houston, M. E. (1984). Annals of Nutrition and Metabolism 28, 123-129.

Powers, S. K., Howley, E. T. \& Cox, R. (1982). Medicine and Science in Sports and Exercise 14, $435-439$.

Richter, E. A. (1984). Acta Physiologica Scandinavica 528 (Suppl.), I-42.

Richter, E. A., Sonne, B., Mikines, K. J., Ploug, T. \& Galbo, H. (1984). European fournal of Applied Physiology 52, 346-350. 
Russell, J. B., Mitchell, D., Musey, P. I. \& Collins, D. C. (1984). Obstetrics \& Gynecology 63, $45^{2-456 .}$

Schmid, P., Wolf, W., Pilger, E., Schwaberger, G., Pessenhofer, J., Pristautx, H. \& Leb, G. (1982). European fournal of Applied Physiology 48, 31 -39.

Shangold, M. M., Gatz, M. L. \& Thysen, B. (1981). Fertility and Sterility 35, 699-702.

Shangold, M. M. \& Levine, H. S. (1982). American fournal of Obstetrics and Gynecology 143, $862-869$.

Simonson, D. C., Koivisto, V., Sherwin, R. S., Ferrannini, E., Hendler, R., Juhlin-Dannfelt, A. \& DeFronzo, R. A. (1984). Fournal of Clinical Investigation 73, $1648-1658$.

Smith, D. M. \& Sugden, P. H. ( 1983 ). Biochemical Yournal $210,55-61$.

Sonne, B. \& Galbo, H. ( 1983 ). Acta Physiologica Scandinavica 118, I8A.

Sonne, B. \& Galbo, H. (1984). Acta Physiologica Scandinavica 120, 5 A.

Sutton, J. R. (1 983 ). In Hypoxia, Exercise, and Altitude, pp. $3^{25} 5^{-33^{8}}$ [J. R. Sutton, C. S. Houston and N. L. Jones, editors]. New York: Alan R. Liss, Inc.

Tabata, I., Atomi, Y. \& Miyashita, M. (1984). Clinical Physiology 4, 299-307.

Tesch, P. A. \& Kaiser, P. (1983). Yournal of Applied Physiology 54, 901-905.

Vanhelder, W. P., Goode, R. C. \& Radomski, M. W. (I984). European fournal of Applied Physiology 52, 255-257.

Viberti, G. C., Home, P. D., Bilous, R. W., Alberti, K. G. M. M., Dalton, N., Keen, H. \& Pickup, J. C. (1984). Acta Endocrinologica 105, 51 5-520.

Wakat, D. K., Sweeney, K. A. \& Rogol, A. D. (1982). Medicine and Science in Sports and Exercise 14, 263-269.

Walker, P. M., Mickle, D. A. G., Tanner, W. R., Harding, R. \& Romaschin, A. D. (1984). American Journal of Physiology 246, $\mathrm{H} 690-\mathrm{H} 695$.

Warten, J. B., Keynes, R. J., Brown, M. J., Jenner, D. A. \& McNicol, M. W. (1982). British Journal of the Diseases of the Chest 76, $147^{-1} 5^{\circ}$.

Weiss, L. W., Cureton, K. J. \& Thompson, F. N. (1983). European Yournal of Applied Physiology 50, 413-419.

Werner, J. C., Whitman, V., Vary, T. C., Fripp, R. R., Musselman, J. \& Schuler, H. G. (1983). American foumal of Physiology 244, E 19-E23.

Williams, R. S. \& Bishop, T. (1 g82). American fournal of Physiology 243, E345-E 35 I.

Williams, R. S., Caron, M. G. \& Daniel, K. (1984). American Yournal of Physiology 246, Er60-EI67.

Winder, W. W., Beattie, M. A. \& Holman, R. T. (1982). American fournal of Physiology 243, $R_{179}-R_{1} 84$.

Zambraski, E. J., Tucker, M. S., Lakas, C. S., Grassl, S. M. \& Scanes, C. G. (1984). American fournal of Physiology 246, $\mathrm{E}_{71}-\mathrm{E}_{7} 6$. 